\title{
Venezuela on the Edge of Bankruptcy: Prospects for Political Change
}

\author{
Sara Toraldo ${ }^{1}$ \\ ${ }^{1}$ Faculty of Economics, Catholic University of the Sacred Heart, Piacenza, Italy and Faculty of Economics, \\ Universidad de las Américas Puebla (UDLAP), México. (Double Degree Programs)
}

Correspondence: Sara Toraldo, Via A.C. Casetti n. 2 Zip Code 73100, Lecce, Italy. E-mail: toraldosara@ gmail.com

Received: August 19, 2019

Accepted: September 6, $2019 \quad$ Available online: September 24, 2019

doi:10.11114/ijsss.v7i6.4538

URL: https://doi.org/10.11114/ijsss.v7i6.4538

\begin{abstract}
Venezuela, a South American petro-giant and the home of the Bolivarian socialist experiment, is in the grip of a grave crisis and an unprecedented political and institutional conflict, which has led to profound economic and social paralysis and a food and health emergency. As of 2019, Venezuela has the highest rate of inflation in the world and is struggling with an economic and social crisis characterised by violence and extreme poverty. In a paradoxical political situation, despite the crisis, the incumbent president Nicolas Maduro refuses to relinquish power while a new figure, Juan Guaidò, virtually unknown a year ago, having proclaimed himself president in January 2019, has been recognised politically by 54 nations, and is seeking a way out of the country's ills. In the first quarter of 2019 alone in Venezuela, 96\% of companies had to drastically reduce their staffing levels and commercial activities, while the average salary of a worker now corresponds to about four euros a month. In addition, in the last twenty years, i.e. since the arrival in power of the previous president, Hugo Chavez, four fifths of Venezuelan companies have closed down or ceased operating after being nationalised. Lastly, $84 \%$ of those who once had employment have now lost it. What the solutions to this situation may consist of is hard to say. This brief paper will look at the series of social and cultural obstacles that hamper any form political change. Cultural and social changes that can help resolve the current political and institutional conflict as soon as possible are required. The country has the largest oil reserves in the world, put at 296.5 billion barrels, and the fourth largest natural gas reserves in the world. In addition, it has the third largest reserves of fresh water on the planet and even possesses huge mineral resources, including gold and diamonds. Despite the variety of resources available, the Venezuelan economy is weighed down by the socialist policies of the government which has neither opened up to more liberal economic policies nor diversified economic investment, thus consolidating the country's complete dependence on petroleum exports, which now account for $96 \%$ of the income from exports and $50 \%$ of state revenues.
\end{abstract}

Keywords: GDP contraction, PDVSA/Petróleos de Venezuela, PROSUR/Forum for the progress and development of South America

\section{Introduction}

Venezuela was once the richest country in Latin America. In terms of wealth and income per capita, it was in the top five countries of the world up until the late 1950s. Its enormous natural wealth kept it among Latin America's wealthiest nations. For years now however, Venezuela, a South American petro-giant and the home of the Bolivarian socialist experiment, has been in the grip of severe economic and social problems. The appalling economic situation has led to a devastating social and humanitarian crisis, reflected in extreme forms of nutritional, health and social poverty (Buxton, 2005, and Buxton, 2011). The current crisis began in 2014 with the fall in the price of crude (from 115 US dollars a barrel in June 2014 to 28 dollars in January 2016), although its roots lie in the government's economic policies. According to data from the International Monetary Fund (IMF), real GDP is expected to fall by $25.0 \%$ in 2019 . After five years of crisis, Venezuela remains trapped in a severe depression due to the collapse in petroleum exports, with a hollowing out of its internal manufacturing base and hyperinflation which is still rising (Mahler, 2011).

\section{Economic Data}

In the last five years, with the intensification of the political crisis, the economic collapse has been significant. The IMF does not calculate the GDP per capita of Cuba, but if we consider the data from other international organisations that receive petroleum from Venezuela, Cuba's current GDP per capita is upper to that of Venezuela (see to website: https://www.imf.org/en/Countries/VEN). The paradoxical aspect of all this is that in the past Cuba benefited from Venezuelan aid and investment for years while in contrast it now sends resources to help Venezuela. Colombia, which 
for decades was a source of migration to Venezuela, is now the main destination for Venezuelan emigration and 2019 its GDP per capita is expected to be double that of Venezuela. The GDP figures for those countries with which Caracas was once accustomed to comparing itself (Chile, Uruguay, Costa Rica, Argentina) are now four to six times higher than Venezuela. In the last four years, only Argentina has seen a fall, though smaller than that of Venezuela (from 14,895 dollars in 2015 to 11,627 in 2019). At over 17,000 dollars, Uruguay is currently South America's richest country, excluding the Bahamas and a few other small Caribbean Anglophone and Dutch nations.

Today, the IMF predicts that in Caracas the situation will continue to worsen. In 2019, GDP will see a further reduction of $25 \%$, inflation will reach $10,000,000 \%$ and the unemployment rate will exceed $44 \%$. The monetary chaos afflicting the country, the lack of reliable data and the refusal of the government to collaborate with the International Monetary Fund have caused what analysts call a "statistical blackout". However, Fitch Solutions Macro Research envisages a fall of 13.9\% in GDP for 2019, following estimated falls of $10.6 \%$ in 2017 and $12.6 \%$ in 2018, reflecting a lowering of predicted petroleum output (see to website: https://www.fitchsolutions.com/bmi-research).

Another aspect to highlight here is the crisis in the oil market, which explains the collapse in production. This affects the state petroleum agency "Petróleos de Venezuela S.A" (PDV SA), which has not been able to invest and reverse the rapid deterioration and ageing of the petroleum infrastructure, or to pay the providers of petroleum production services. Fitch Solutions estimates that the state oil company PDV SA reduced production by $29.3 \%$ in 2018 and will do so by $31.2 \%$ in 2019 , further lowering state revenues. In addition, inflation is expected to exceed $1,700,000 \%$ by the end of 2019 , due to the printing of money and the shortage of basic goods. The rising quantity of money in circulation is worth less and less, resulting in exponential price rises. The Central Bank of Venezuela was forced to remove five zeroes from banknotes, issuing a new currency, the "Bolivar Soberano". The reduced or almost non-existent monetary purchasing power of families has made the Venezuelan banking system unable to function, and it is understood that the shortage of hard currency has forced Venezuela to apply huge cuts to imports. In November 2017, imports briefly increased when Venezuela defaulted on its public debt, but they remain well below the needs of the national economy. A further problem is the brain drain, the steady emigration of qualified workers, particularly from the state oil company PDV SA, which has had grave economic consequences of its own and has reduced the human capital that might enable the economic infrastructure of Venezuela to function more effectively. Emigration is both a cause and a consequence of the economic crisis, in that the decline in living standards in the country has accelerated migration towards other countries in Latin America. Every day, a large number of Venezuelans cross the "Bolivar" bridge into Colombia to obtain food and medicine. In 2018 5,000 people are estimated to have left the country every day, making a total of three million, which is predicted to rise to five million in 2019. This humanitarian crisis has also intensified the black-market trade in American dollars among the Venezuelan population. PDV SA's unpaid employees could opt to go in search of better conditions abroad, for example by seeking work in the storage and refining facilities of other oil firms elsewhere in the Caribbean, or in other companies such as Citgo, an American subsidiary of PDV SA (see to website: https://www.reuters.com/article/venezuela-economy/update-1-in-rare-release-of-economy-data-venezuela-reports-sharpgdp-contraction-idUSL2N2341I2).

\section{Talking Points}

The crisis has a number of causes. Political corruption, poor management of public finances and the fall in the price of petroleum have all contributed to a gradual worsening of the economic and social situation in Venezuela over time. However, an additional factor has been the negative role played by government economic policies under both Chavez and later Maduro, including currency exchange and consumer price controls, expropriations and the clumsily executed nationalisation of private companies. These policies have gradually brought the Venezuelan economy to a state of ruin, to such an extent that the IMF has compared the crisis to what is seen in countries affected by armed conflict.

The joint responsibility of the Bolivarian governments of Hugo Chavez (1999-2013) and then Nicolás Maduro (2013 to the present) for the Venezuelan macroeconomic disaster are now clear, and we shall list some aspects of this here. Regarding the poor management of public finances, we may cite certain questionable political decisions by the Chavez government which the state simply could not afford, such as the enormous social programmes, state subsidies for healthcare and education and poverty reduction schemes (including the "Robinson" and "El Mercal" initiatives), which won the regime popularity and democratic support in its early years. Another political decision, ill-conceived in economic terms and of no benefit, was the allocation of public funds for the purchase of advanced military hardware. A further mistake was the decision to grant huge loans to friendly countries such as Bolivia, Cuba, Nicaragua, Ecuador and Argentina with no effective return for the state. Then there were the cuts to investment in the hydrocarbon sector, which had the effect of progressively increasing the deficit, generating considerable fiscal problems (Restuccia, 2018 and Tariq Ali, 2006).

The political and institutional crisis has pitted the current government of president Nicolas Maduro, ex foreign minister 
and protégé of the late Hugo Chavez, against the opposition forces who have banded together under the leadership of Juan Guaidò Márquez, president of the National Assembly of Venezuela since January $5^{\text {th }} 2019$. On January $23^{\text {rd }} 2019$, during a political demonstration in Caracas, Juan Guaidò Márquez took the oath as president of Venezuela ad interim, triggering a political and institutional crisis and a direct clash with the elected president Nicolas

Maduro (see to website:

https://www.theguardian.com/world/2019/jan/15/juan-guaido-venezuelan-opposition-leader-challenging-maduros-rule). Political change in this situation appears to be increasingly difficult due to the historically and socially deep-rooted support for Chavismo, which in its early years succeeded in winning over Venezuelans to the socialist programmes that reinforced his anti-democratic and anti-liberal economic strategies. Over time, the mass propaganda policies, implemented via radio programmes such as the famous "Chavez de repente", have subconsciously influenced the consciousness of the Venezuelan people, making them more receptive towards government programmes whose political purpose is to gain support and convince the population that the nation's resources should be exclusively for Venezuelans. This strategy has been continued by Maduro. The manipulation of popular consciousness by Chavismo, reinforced by the national media loyal to the regime, survives under Maduro, and the people are no longer willing to accept sudden political change that might lead to the reforms necessary for the longed-for economic improvement (Guy, 2012 and Hausmann et al, 2014).

A further obstacle to toppling the Maduro government its strong internal support among the army. The government has developed a special relationship with the armed forces, which have always backed the socialist government. In the long term, the greatest political risk is that by clinging on to power, the government led by Nicolas Maduro and the Partido Socialista Unido de Venezuela (PSUV) will generate severe political instability. Together with Maduro, the PSUV has shown itself to be unable to tackle the economic crisis in Venezuela. However, it strengthened it grip on power in the course of 2018, suggesting that it may seek to remain in office until 2020 (Baena, 2019 and Page et al, 2019).

The difficulty in dislodging Maduro and his government is linked to a series of other factors, important among which is the enormous social fragmentation of Venezuelan society initiated by Hugo Chavez in which the government emphasised class conflict, pitting rich against poor and highlighting the enormous difference between social classes (Timothy, 2019 and Petkoff , 2007). Chavez posed as a class warrior, allocating substantial resources and subsidies to the poorer social classes (for example via the "Robinson" and "El Mercal" educational programmes), but these were not accompanied by other public policies to ensure social equilibrium, and thus made class antagonism even worse, causing a deep fracture that has not been repaired (Sylvia \& Danopoulos, 2010 and Zúquete, 2008). Other factors that enable Maduro to maintain his grip on power include the fear of many Venezuelans that they will lose their government jobs, considering that almost $80 \%$ work in the public sector. The fear among the population of losing one's job dates back to the Chavez government, when National Assembly member Luis Tascón published the so-called "Lista Tascón", a blacklist containing all the names of those who had signed a petition calling for the recall of President Chavez and were duly persecuted. In the same way, Nicolas Maduro has also persecuted many politicians who have dared to oppose him, such as Leopoldo Lopez, Henrique Capriles, Freddy Guevara, Maria Carina Machado and Henry Ramos Allup (Buxton, 2018 and Michelutti, 2013).

Another problem contributing to the political stalemate is the high level of common and political criminal activity linked to the Revolutionary Armed Forces of Colombia, who have a close relationship with Maduro. The FARC are seeking to expand the international drugs trade, taking advantage of the political backing of Maduro and the poorly policed border between the two countries (Romero et al., 2013). This has further inflamed the diplomatic tension between Venezuela and the United States. Chavez always sought the support of the FARC against the US, dreaming of the resurrection of "La Gran Colombia" (a state created after independence from Spain which included the modern-day territory of Venezuela, Colombia and Ecuador), a socialist state that would be the starting point for a project to unite the whole of the South American continent under the same flag in defiance of US economic interests. While the Americans fought the FARC, deeming them to be a band of international narco-traffickers seeking to distribute drugs in the USA, the FARC supported the policies of the Venezuelan government and Chavez's dreams of geopolitical supremacy in return for political and diplomatic assistance that enabled them to maintain the lucrative drugs trade. Lastly, due to these diplomatic and military conflicts, the USA stopped importing petroleum from Venezuela and increased imports from other Latin-American countries. Measured in thousands of barrels a day, compared to March 2018, American imports from Venezuela have fallen from 506 to 0, while imports from Mexico have increased from 534 to 712, from Colombia from 228 to 421, from Ecuador from 20 to 197 and from Brazil from 0 to 175. The production of petroleum in Venezuela is thus expected to fall further, due to both the lack of investment and the American sanctions, from 1.3 million barrels a day in 2018 to about 750,000 in 2019. This will allow other producers, including Mexico and Brazil, to expand their production at the expense of Venezuela (see to website https://edition.cnn.com/2019/03/21/business/venezuela-oil-imports-united-states/index.html).Venezuela is thus predicted to remain trapped in a deep depression in 2019 and 2020. 


\section{Conclusions and Future Directions}

The economic crisis has eroded some of the plebiscitary political support that socialist Chavismo once enjoyed. From the political point of view, Venezuela needs to repair the internal political and institutional fracture in order to begin the work of economic recovery. In the light of the above considerations concerning Chavez's policies, it is hoped that a liberal economic approach with diversification of investment, reversing the politically-driven decisions of the past, can be adopted. Political change should not be abrupt, but gradual, accompanied by a process of social education that makes the Venezuelans aware of the new political strategies to adopt. This would make it possible to shed the ideological prejudices to which the population has been subjected in the decades since the advent of Chavismo. For this reason, it is hoped that the urgent political change can unfold via choices mediated by a "cluster economy", involving interaction between the academic and social sectors. This will enable the development of a collective popular intelligence that can embrace suitable policies and specific social roles, by means of shared learning processes (Mills, et al. 2008). This process of political and social change can be mediated by an independent international socio-economic organisation such as the Organisation for Economic Co-operation and Development (OECD), which is an international organisation that works to build better policies for better lives, the goal being to shape policies that foster prosperity, equality, opportunity and well-being for all (O.E.C.D., 2019).

Together with local opinion leaders, this organisation can help the country to adopt suitable economic policies that can match the complexity of the situation and help the population to cope during the difficult transition period. In addition, a key diplomatic role can be played in the resolution of the Venezuelan crisis by regional South American diplomacy. In July 2019, international diplomacy under the guidance of the Norwegian government was unsuccessful. This followed earlier failures in 2016 and 2018. There are various factors however that indicate that this time the negotiations may have greater success. Both sides now have greater incentives to come to a political and institutional agreement and prevent the economic and social crisis from worsening further. At this point the regional diplomatic initiative can be orchestrated by the governments of Brazil, Ecuador and Colombia, acting under the aegis of the Forum for the Progress and Development of South America (PROSUR) to provide a cooperative and constructive geographical context. In this way, it is hoped that the Venezuelan government can be brought to the negotiating table in order to agree a way out of the internal institutional impasse. Venezuela must resume investment in petroleum and seek to privatise the management of its petroleum reserves, which are the largest in the world, put at 296.5 billion barrels. If liberalised, this resource can become a powerful engine of development. In addition, Venezuela has the fourth largest reserves of natural gas, the third largest reserves of fresh water and huge mineral resources, including gold and diamonds.

To these important natural resources may be added the significant potential of other sectors including agriculture and food processing, pharmaceuticals and transport infrastructure. This requires a diversified investment plan that is no longer concentrated in the hands of the state but left to the entrepreneurship of the private sector.

\section{Disclosure}

The author declare that do not have any conflicts of interest or financials.

\section{References}

Baena, E. C. (2019). The Policy Process in a Petro-State an Analysis of PDVSA's (Petróleos de Venezuela SA's) Internationalization Strategy, London, Routledge. https://doi.org/10.4324/9780429442964

Buxton, J. (2005). Venezuela's Contemporary Political Crisis in Historical Context. Bulletin of Latin American Research, 24, 328-347. https://doi.org/10.1111/j.0261-3050.2005.00138.x

Buxton, J. (2011). Forward into History. Latin American Perspectives, 38, 4-29. https://www.jstor.org/stable/i23060113

Buxton, J. (2018). The Failure of Political Reform in Venezuela, London, Routledge. https://doi.org/10.4324/9781315205106

CNN Business. (2019 March 21). by Matt Egan, CNN Business, America imported no oil from Venezuela last week Here's why that's a big deal. Retrieved from https://edition.cnn.com/2019/03/21/business/venezuela-oil-imports-united-states/index.html

Fitch Solutions, Latin America Monitor. (2019). Andean: Venezuela in The Midst of a Depression, With Risks to The Downside, February Vol. 36 Issue 2. Retrieved from https://www.fitchsolutions.com/bmi-research

Guy, R. E. (2012). Promoting ‘American’ democracy. Social Identities, 18(6), 629. https://doi.org/10.1080/13504630.2012.708993

Hausmann, R. K., \& Rodríguez, F. R. (2014). Venezuela Before Chávez: Anatomy of an economic collapse. Retrieved from books.google.com 
International Monetary Fund (IMF) 2019. website: https://www.imf.org/en/Countries/VEN

Mahler, A. (2011). Oil in Venezuela: Triggering Conflicts or Ensuring Stability? A Historical Comparative Analysis. Politics \& Policy, 39(4), 583-611. Wiley Online Library. https://doi.org/10.1111/j.1747-1346.2011.00305

Michelutti, L. (2013). Post-secularity and political hope in 21st century socialism. In T. Muhr (ed.), Counter-globalization and socialism in the 21st century: The Bolivarian alliance for the peoples of our America. London/New York: Routledge. https://doi.org/10.4324/9780203503874

Mills, K. G., Reynolds, E. B., \& Reamer, A. (2008). Clusters and Competitiveness: A New Federal Role for Stimulating Regional Economies, Metropolitan Policy Program, Brookings.

OECD/CAF/UN ECLAC. (2019). Latin American Economic Outlook 2019: Development in Transition, OECD Publishing, Paris. https://doi.org/10.1787/g2g9ff18-en

Page, R., Doocy, S., Reyna, G. F., Castro, J. S., Spiegel, P., \& Beyrer, C. (2019). Venezuela's public health crisis: a regional emergency. The Lancet, 393(10177): 23-29. https://doi.org/10.1016/s0140-6736(19)30344-7.

Petkoff, T. (2007). The Two Lefts: Chavez, Venezuela, and Contemporary Left-Wing Politics, Lulu.com.1. Business \& Economics, 85.

Restuccia, D. (2018). The Monetary and Fiscal History of Venezuela: 1960-2016; 20: 2018.University of Chicago, Becker Friedman Institute for Economics Working. https://doi.org/10.2139/ssrn.3237748

Reuters Bonds. (2019, may 29). update 1-In rare release of economy data, Venezuela reports sharp GDP contraction. Retrieved from

https://www.reuters.com/article/venezuela-economy/update-1-in-rare-release-of-economy-data-venezuela-reports-s harp-gdp-contraction-idUSL2N2341I2

Romero, C. A., \& Kelly, J. (2013). United States and Venezuela Rethinking a Relationship. Routledge. https://doi.org/10.4324/9781315023441

Sylvia, R., \& Danopoulos, C. (2010). The Chávez phenomenon: Political change in Venezuela. Third World Quarterly, 24(1), 63-76. https://doi.org/10.1080/713701367

Tariq, A. (2006). The Latin American Challenge: Chavez, Morales, Castro. Institute for Social Science Research, Working Paper Series from Institute for Social Science Research, UCLA. Retrieved from https://EconPapers.repec.org/RePEc:cdl:issres:qt3b17628b

The Guardian. (2019, 23 Jan). Venezuela: who is Juan Guaidó, the man who declared himself president? Retrieved from https://www.theguardian.com/world/2019/jan/15/juan-guaido-venezuelan-opposition-leader-challenging-maduros-r ule

Timothy, G. (2019). Politics, human rights, and social policy under contemporary populist regimes: The view from Trump-America and socialist Venezuela. Irish Journal Sociology. https://doi.org/10.1177/Sage-Journals-Update-Policy.

Zúquete, J. (2008). The missionary politics of Hugo Chávez. Latin American Politics and Society,50: 91-121. https://doi.org/10.1111/j.1548-2456.2008.00005

\section{Copyrights}

Copyright for this article is retained by the author(s), with first publication rights granted to the journal.

This is an open-access article distributed under the terms and conditions of the Creative Commons Attribution license which permits unrestricted use, distribution, and reproduction in any medium, provided the original work is properly cited. 